\title{
AKTIVITAS ANTIRADIKAL BEBAS SENYAWA TURUNAN CALKON DAN TURUNAN BENZOTIAZEPIN
}

\author{
Sulismayati, Jasril, Christine Jose, Rahmiwati Hilma \\ Universitas Riau \\ Universitas Muhammadiyah Riau \\ Email: sis.adam2007@gmail.com
}

\begin{abstract}
ABSTRAK
Senyawa calkon merupakan flavonoid rantai terbuka dengan cincin aromatik yang dihubungkan oleh tiga atom karbon dengan system $\alpha, \beta$ karbonil keton tidak jenuh. Calkobn juga merupakan senyawa antara untuk membuat senyawa lain salah satunya adalah benzotiazepin. Benzotiazepin adalah senyawa heterosiklik yang mengandung nitrogen dan sulfur. Hasil uji aktivitas anti radikal bebas dari senyawa calkon $\mathrm{Y}_{1}$ dan senyawa benzotiazepin $\mathrm{Bt}_{1}$ memperlihatkan aktivitas yang sangat lemah, ditandai dengan nilai $\mathrm{IC}_{50}$ yang lebih besar dari 1000 ppm jika dibandingkan dengan standar yang digunakan yaitu vitamin $\mathrm{C}$ dengan nilai $\mathrm{IC}_{50} 33,539 \mathrm{ppm}$. Hal ini mungkin disebabkan karena tidak adanya substituen ataupun gugus yang dapat menyumbangkan proton pada kedua senyawa hasil sintesis sehingga menyebabkan kedua senyawa tersebut tidak aktif sebagai antiradical bebas.
\end{abstract}

Kata kunci: calkon, benzotiazepin, uji antiradikal bebas

\section{PENDAHULUAN}

Antioksidan adalah senyawa kimia yang dapat memperlambat atau menghambat terjadinya proses oksidasi yang disebabkan oleh radikal bebas. Radikal bebas adalah molekul yang kehilangan elektron, sehingga molekul tersebut menjadi tidak stabil. Untuk mengembalikan kestabilan molekul diperlukan elektron dari molekul antioksidan seperti elektron dari polifenol (Esmaeili dan Sonboli, 2010). Senyawa polifenol berperan penting pada stabilisasi lipid terhadap peroksidasi dan menghambat oksidasi enzim.

Calkon merupakan salah satu senyawa alam yang mempunyai aktivitas biologis beragam. Sejumlah senyawa calkon telah dilaporkan mempunyai aktivitas antibakteri. Aktivitas antibakteri ini dihubungkan dengan adanya gugus keton $\alpha$ dan $\beta$ tak jenuh dalam sistem C-karbonil (Nowakowska, 2007). Selain berpotensi sebagai antibakteri, senyawa calkobn juga memiliki aktivitas lain seperti antioksidan, anti inflamasi, anti tuberkulosis, antifungi, anti malaria dan anti kanker (Prasad et al, 2006). Keberadaan senyawa calkobn dialam relatif sedikit begitu juga dengan variasi strukturnya, sehingga menyulitkan mengisolasi senyawa calkon dari tumbuhan. Berdasarkan hal tersebut, maka didapatkan suatu solusi yang dapat meminimalisir segala kekurangan dalam proses isolasi yaitu dengan mensintesis senyawa calkobn tersebut dialam (Alam, 2004).

Pengembangan penggunaan senyawa calkon dilakukan dengan memodifikasi substituen pada kerangka dasarnya melalui sintesis kimia. Modifikasi substituen pada kerangka dasar senyawa-senyawa kimia bertujuan untuk meningkatkan aktivitas farmakologi dan atau mengurangi efek yang tidak diinginkan pada suatu senyawa kandidat obat. Turunan senyawa calkobn dapat disintesis secara luas melalui kondensasi Claisen-Schmidt dari suatu 
aldehid aromatik dengan keton aromatik dalam kondisi asam atau basa (Bag et al., 2009; Power et al., 1998; Claisen et al., 1881). Rateb dan Zohdi (2009) telah berhasil mensintesis senyawa calkobn dengan metoda gerus menggunakan katalis $\mathrm{NaOH}$ dan mendapatkan hasil dengan jumlah rendemen diatas $80 \%$.

Calkon juga merupakan senyawa antara untuk membuat senyawa lain salah satunya adalah benzotiazepin. Benzotiazepin adalah senyawa heterosiklik yang mengandung nitrogen dan sulfur (Vyawahare et al, 2010) merupakan senyawa yang penting dalam obat dan penelitian farmasi. Sejumlah turunan benzotiazepin dilaporkan mempunyai aktivitas biologi yang menarik seperti anti konvulsan (Sarro et al, 1995), anti depresi (Vyawahare et al, 2010), anti kanker (Sharma et al, 1997), anti fungal (Anshu et al, 2007), anti HIV (Giuliano, 1999) dan anti mikroba (Nikalje, 2011). Hal inilah yang menarik banyak peneliti untuk mengembangkannya.

Senyawa antioksidan saat ini bermanfaat dalam berbagai bidang seperti dalam bidang pangan, industri tekstil, minyak bumi, bahan pewarna dan lain-lain. Riset tentang pengembangan senyawa berkhasiat antioksidan telah banyak dikembangkan baik senyawa alam maupun senyawa sintetis. Keberadaan senyawa calkon di alam relatif kecil, maka sulit memperolehnya melalui isolasi dari bahan alam. Oleh karena itu, sintesis diharapkan dapat mengatasi masalah ini dengan menghasilkan berbagai analog calkon dan benzotiazepin yang strukturnya lebih bervariasi. Hal ini sangat membantu dalam uji aktivitasnya sebagai antioksidan.

Penelitian ini bertujuan untuk Uji aktivitas antiradikal bebas dari senyawa calkon dab benzotiazepin hasil sintesis yang dilakukan dengan metoda DPPH. Manfaat dari penelitian ini yaitu untuk aplikasi dan pengembangan ilmu pengetahuan. Penelitian ini diaplikasikan dalam kandidat molekul obat calkon dan benzotiazepin sebagai antioksidan.

\section{METODE PENELITIAN}

\section{Alat}

Alat-alat yang digunakan adalah alat-alat untuk uji antioksidan seperti plat uji, microplate reader, serta peralatan gelas yang umum digunakan di laboratorium kimia.

\section{Bahan}

Bahan-bahan yang digunakan, nheksana, etilasetat, metanol, etanol absolut, aquadest dingin, $\mathrm{NaOH}$ (Merck). 2,2diphenyl-1-picrylhydrazyl (DPPH) (Sigma) dan asam askorbat.

Sampel yang digunakan adalah senyawa calkon (E)-1,3-di(naftalen-1-il)prop-2pen-1on dan senyawa turunan benzotiazepin $(E)$ 2,4-di(naftalen-1-il)-2,3-dihidrobenzo $(1,4)$ tiazepin hasil reaksi sintesis, yang telah disintesis dan dikarakterisasi dari penelitian sebelumnya

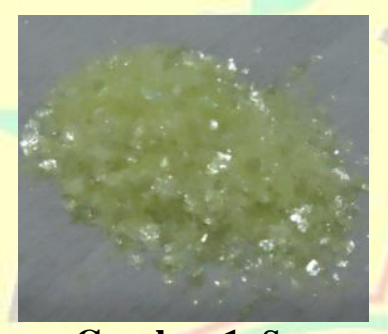

Gambar 1. Senyawa $\mathrm{Y}_{1}$ dan Senyawa $\mathrm{Bt}_{1}$

\section{Analisis total aktivitas antiradikal bebas dengan uji DPPH}

Uji aktivitas antiradical bebas dilakukan menggunakan mikroplate reader (plate terdiri dari baris A-H masing-masing berjumlah 12 sumur) dengan metoda DPPH (Zhang et al., 2006) pada panjang gelombang $520 \mathrm{~nm}$.

Sampel sebanyak $2 \mathrm{mg}$ dilarutkan dalam $2 \mathrm{ml} \mathrm{MeOH}$, dalam hal ini konsentrasi 
sampel adalah $1000 \mathrm{mg} / \mathrm{ml}$. Baris A dimasukkan sampel sebanyak $100 \mu \mathrm{L}$. Sebanyak $50 \mu \mathrm{L} \mathrm{MeOH}$ dimasukkan pada masing-masing sumur B-F. Baris A dipipet sebanyak $50 \mu \mathrm{L}$ dan dimasukkan ke baris $\mathrm{B}$, baris B dipipet $50 \mu \mathrm{L}$ dimasukkan ke baris C dan dilakukan sampai baris F, baris F dipipet $50 \mu \mathrm{L}$ lalu dibuang, sehingga didapatkan konsentrasi $1000 \mathrm{mg} / \mathrm{ml}, 500 \mathrm{mg} / \mathrm{ml}, 250$ $\mathrm{mg} / \mathrm{ml}, \quad 125 \mathrm{mg} / \mathrm{ml}, \quad 62,5 \mathrm{mg} / \mathrm{ml}, \quad 31,25$ $\mathrm{mg} / \mathrm{ml}$. Sedangkan pada baris G-H diisi dengan metanol $50 \mu \mathrm{L}$, khusus pada baris $\mathrm{H}$ diisi hanya sumur 1-6. Baris A-G ditambahkan DPPH sebanyak $80 \mu \mathrm{L}$ dengan konsentrasi $40 \mathrm{mg} / \mathrm{ml}$, kemudian diinkubasi selama 30 menit.

Aktivitas penangkapan radikal bebas diukur sebagai penurunan absorbansi DPPH dengan mikroplate Aktivitas penangkapan radikal bebas diukur sebagai penurunan absorbansi DPPH dengan mikroplate reader dan olah data. Kontrol positif yang digunakan sebagai pembanding yaitu vitamin C. Nilai \% hambatan dihitung dengan rumus:

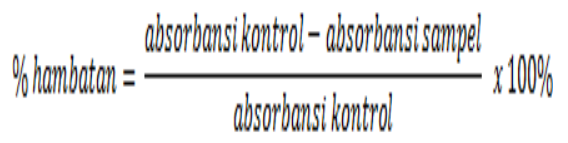

\section{HASIL DAN PEMBAHASAN}

Berdasarkan dari penelitian yang telah dilakukan, diperoleh hasil Uji aktivitas antiradical bebas senyawa $\mathrm{Y}_{1}$ dan $\mathrm{Bt}_{1}$ dilakukan menggunakan metode

DPPH. Vitamin $\mathrm{C}$ digunakan sebagai standar. Hasil uji aktivitas antioksidan senyawa hasil sintesis $\mathrm{Y}_{1}$ dan $\mathrm{Bt}_{1}$ dapat dilihat pada tabel 1

Tabel 1. Hasil Uji Aktiviras Antioksidan

\begin{tabular}{|c|c|c|c|c|}
\hline Sampel & Konsentrasi (ppm) & Absorbansi & \%Hambatan & IC50 (ppm) \\
\hline \multirow[t]{6}{*}{$\mathrm{Y}_{1}$} & 1000 & 0,215833 & 11,1797 & $>1000$ \\
\hline & 500 & 0,308 & 5,1440 & \\
\hline & 250 & 0,307 & 5,5555 & \\
\hline & 125 & 0,314333 & 2,5377 & \\
\hline & 62,5 & 0,321333 & $-0,3429$ & \\
\hline & 31,25 & 0,318 & 1,0288 & \\
\hline \multirow[t]{6}{*}{$\mathrm{Bt}_{1}$} & 1000 & 0,221833 & 8,7105 & $>1000$ \\
\hline & 500 & 0,227167 & 6,5157 & \\
\hline & 250 & 0,237167 & 2,4005 & \\
\hline & 125 & 0,2395 & 1,4403 & \\
\hline & 62,5 & 0,2405 & 1,0288 & \\
\hline & 31,25 & 0,260833 & $-7,3388$ & \\
\hline \multirow[t]{6}{*}{ Vitamin C } & 100 & 0,0205 & 91,5637 & 33,539 \\
\hline & 50 & 0,035833 & 85,2537 & \\
\hline & 25 & 0,1045 & 56,9958 & \\
\hline & 12,5 & 0,1655 & 31,893 & \\
\hline & 6,25 & 0,199167 & 18,0384 & \\
\hline & 3,25 & 0,212167 & 12,6886 & \\
\hline
\end{tabular}

\section{Uji antioksidan}

Pada penelitian ini uji antioksidan terhadap senyawa $\mathrm{Y}_{1}$ dan $\mathrm{Bt}_{1}$ dilakukan dengan metode DPPH (Zhang et al., 2006) pada panjang gelombang $520 \mathrm{~nm}$. Analisis ini dinyatakan dengan $\mathrm{IC}_{50}$ sebagai indikator kemampuan hambatan sebesar 50\% sampel uji dengan menggunakan vitamin $\mathrm{C}$ sebagai kontrol positif.

Hasil uji antioksidan dari senyawa $\mathrm{Y}_{1}$ dan $\mathrm{Bt}_{1}$ memperlihatkan aktivitas antioksidan yang lemah, ditandai dengan nilai $\mathrm{IC}_{50}$ yang lebih besar dari 1000 ppm jika dibandingkan dengan standar yang 
digunakan yaitu vitamin $\mathrm{C}$ dengan nilai $\mathrm{IC}_{50}$ 33,539 ppm. Hal ini mungkin disebabkan karena tidak adanya substituen ataupun gugus yang dapat menyumbangkan proton pada kedua senyawa hasil sintesis sehingga menyebabkan kedua senyawa tersebut tidak aktif sebagai antioksidan.

\section{KESIMPULAN DAN SARAN}

\section{Kesimpulan}

Berdasarkan hasil penelitian yang telah dilakukan, maka dapat diambil kesimpulan diantaranya sebagai berikut.

1. Kedua senyawa calkon dan benzotiazepin tidak aktif sebagai antioksidan.

2. Tidak adanya substituen ataupun gugus yang dapat menyumbangkan proton pada kedua senyawa hasil sintesis menyebabkan kedua senyawa tidak aktif sebagai antioksidan.

\section{Saran}

1. Agar diperoleh hasil yang lebih baik pada penelitian-penelitian selanjutnya, maka penulis menyarankan hal-hal sebagai berikut.

2. Perlu dilakukan pengujian aktivitas biologi lainnya, agar senyawa yang telah disintesis diketahui pemanfaatan dan kegunaannya lebih lanjut.

3. Untuk penelitian sintesis analog calkobn naftalen berikutnya disarankan agar menggunakan asetilnaftalen ataupun naftaldehid yang memiliki substituen.

\section{DAFTAR PUSTAKA}

Alam, S.,2004. Synthesis, Antibacterial and Antifungal of Some Derivates of 2phenyl-4-one, J.Chem.Sci.116.325331

Al-Mamun, M., Yamaki, K., Masumizu, T., Nakai, Y., Saito, K., Sano, H., Tamura, Y. 2007. Superoxide Anion Radical Scavenging Activities of
Herbs and Pastures in Northern Japan Determined Using Electron Spin Resonance Spectrometry. Int $J$ Biol Sci. 3:349-355

Andarwulan, N., Batari, R., Sandrasari, D.A., Bolling, B., Wijaya, H. 2010.

Flavonoid content and Antioxidant Activity of Vegetables from Indonesia. Food Chemistry. 121: 1231-1235

Ameta, K.L., Nitu,S., Rathore and Kumar,B. 2012. Synthesis and in vitro anti breast cancer activity of some novel 1,5-benzothiazepine derivates, J.Serb.Chem.Soc.76, 1-17

Anshu, D., Singh, R., Khaturia, S., 2007. Efficient microwave enhance solvent free synthesis of potent antifungal agents Fluorinated benzotiazepines fused $\quad \beta$-lactam derivative, Cheminform. 38(36).236-239

Arora, V., Arora, P., Lamba, H.S.,2012. Synthesis and Evaluation of Chalcone Derivatives of 2-acetyl naphthalene for Antifungal and Antibacterial Activity. Der Pharmacia Lettre, 4 (2):554-557

Bag, S., Ramar, S., degani, M.S., 2009, "Synthesis and Biological Evaluation of $\alpha, \beta$-Unsaturated Ketone as Potential Antifungal Agen", Med Chem. Res., 18, 309-316

Claisen, L., Claparede, A., Schmidt, J.G, 1881, "Condensation of Aromatic Aldehydes and Aliphatic Aldehydes or Ketones in The Presence of Aqueous Base", Ber, 14:2460, 1459.

Esmaeili, M.A., Sonboli, A. 2010. "Antioxidant, Free Radical Scavenging Activities of Salvia brachyantha and Its Protective Effect Against Oxidative Cardiac Cell Injury". Food and Chemical Toxicology (48): 846-853

Giuliano, G., Luana, R., Valeria, A., 1999, "Synthesis of new 1,4benzotiazepines tricyclic derivative with structural analogue with TIBO and their screening for anti-HIV 
activity", Eur. Journal of Medicinal Chemistry. 34(9), 701-709.

Gritter, R.J., 1991, J.M Bobbit, A.E Schwarting, Pengantar kromatografi, ITB, Bandung.

Ketaren, S. 1986. Minyak dan Lemak Pangan. Universitas Indonesia Press. Jakarta

Krishnaiah, D., Sarbatly, R., Nithyanandam, R. 2010. A Review of the Antioxidant Potential of Medicinal Plant Species. Food and Bioproduct Processing. 157:17-34

Mistry, K. M., Desai, K.R.,2005, Microwave Assisted Rapid and Efficient Synthesis \& Pharmacological Evaluation of 1,5-Benzothiazepine, J. Saudi Chem. Soc., 9(2), 381-386

Moon JK, Shibamoto T. 2009. Antioxidant Assays for Plant and Food Component. Journal of Agricultural and Food Chemistry. 57: 1655-1666

Nam, N.H., Hong, D.H., You, Y.J., Kim, Y., Bang, S.C., Kim, H.M., Ahn, B.Z.,2004, "Synthesis and Cytotoxicity of 2,5Dihydroxychalcones and Related Compounds", Arch Pharm Res, 27(6), 581-588.

Nikalje, A.G., Mane, R.A., Ingle DB, 2006, Synthesis of New 1,5Benzotiazepines as Potent Antimicrobial agents, Ind. J.Het.Chem, 15(3), 309-310

Nikalje, A.P., Vyawahare, D.,2011, Facile green Synthesis of 2,4-substituted2,3-dihydro-1,5-benzotiazepine derivative as novel anticonvulsant and Chentral Nervous System (CNS) depressant agents, African Journal of Pure and applied chemistry, Vol 5(12), 422-428

Nowakowska, Z., 2007, "A Review of Antiinfective and Anti-inflammatory Chalcone", European Journal of Medicinal Chemistry, 42, 125-137

Palleros, D.R. (2004)."Solvent free synthesis of chalcones". J. Chem. Ed, 81, 1345-1347.
Powers, D.G., Casebier, D.S., Fokas, D., Ryan, W.J., Troth, J.R., Coffen, D.L., 1998, "Automated parallel synthesis of chalcone-based screening libraries", Tetrahedron Lett, 54, 4085-4096.

Prasad, Y.R.; Kumar, P.R.; Deepti, C.A.; Ramana, M.V. (2006). "Synthesis and antimicrobial activity of some novel chalcones of 2-hydroxy-1acetonapthone and 3-acetyl coumarin”. E-Jornal of Chemistry, $\mathbf{3}$, 236-241.

Prokarny, J., 1987, In Autooxidation of Unsaturated Lipids, Academia Press, New York.

Rateb, N.M and Zohdi, H.F, 2009, "AtomEfficient, Solvent-Free, Green Synthesis of Chalcones by Grinding", Synthesis Communications, 39, 2789-2794

Sanjeeva, R., Cherkupally., Purnachandra, R and Gurrala. 2008, Synthesis and biological study of novel methylenebis-benzofuranyl-(1,5)-

benzothiazepin, Org. Commun 1:4, 84-94

Sarro, J.G.,Chimirri,A. and Sarro, A, D.,1995. 5H-(1,2,4)-oxadiazolo- $(5,4-$ d)(1,5)-benzotiazepine as anticonvulsant agents in DBA/2 miceur. Med Chem.30.925-929

Sharma, K.,Singh, G., Yadav, A.K. and Prakash, L.,1997, Improved method for Synthesis of new 1,5benzotiazepines derivative as analogue of anticancer drugs. Molecules.2(2).130-135

Sharp, J., I. Gosney, A.G Rowley, 1989, Practical Organic Chemistry: A Student Handbook of Techniques, Chapman and Hall, London.

Sastrohamidjojo, H., 1991, Dasar-dasar Spektroskopi, Ed II, Liberty, Universitas Gajah Mada, Yogyakarta.

de Vincenzo, R., Scambia, G., Mancuso, S., 1995, "Effect of synthetic and naturally occurring chalcones on ovarian cancer cell growth: 
structureactivity relationships", Anticancer Drug Des, 10, 481-490

Vyawahare,D.,Ghodke, M. and Nikalje,A.P., 2010. Green Synthesis and Pharmacological Screening of novel 1,5-benzotiazepines as CNS agents, International Journal of Pharmacy and Pharmaceutical Science, Vol 2

Yadaf, J. S., Srivastava, Y.K., 2011, Microwave Assisted Rapid and Efficient Synthesis, Characterization and Pharmacological Evaluation os
Some Novel Benzimidazole Assemble 1,5-Benzodiazepine and 1,5-Benzothiazepine Derivatives, Sholarrs Research Library, 284-291

Yoshihara, D., Fujiwara, N., Suzuki, K. 2010. Antioxidants: Benefits and risks for long-term health. Maturitas. G Model MAT-5378: 5-10

Zamri, A., Eryanti, Y., Jasril. 2007. "Sintesis dan aktivitas antimikroba 3 analog calkon.

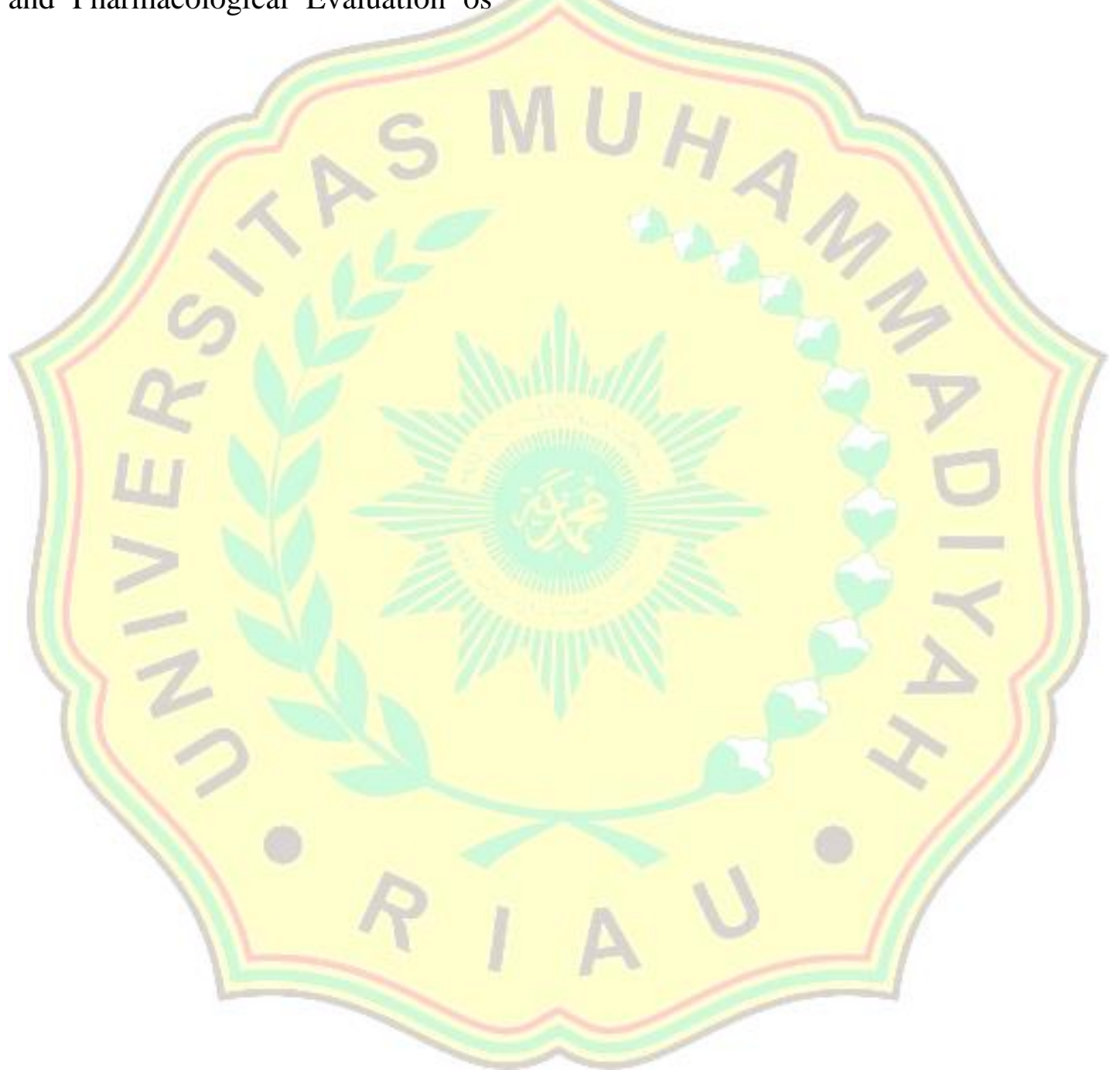

